\title{
Governing bird-keeping in Java and Bali: evidence from a household survey
}

\author{
PAUL JEPSON and RICHARD J. LA DLE
}

\begin{abstract}
The Indonesian pastime of keeping wild birds as pets is threatening the long-term survival of many songbird species on the islands of Java and Bali. Here we present the results of a large-scale household survey of bird-keeping in the six largest cites of Java and Bali that investigates: (1) the scale and conservation significance of bird-keeping and (2) the relative merits of regulatory versus market-based approaches as means to reduce the enormous demand for wildcaught birds. We found bird-keeping is widespread across social groups, with a rising demand for certain species of conservation importance. Specifically, $35.7 \%$ of households surveyed keep a bird and $57.6 \%$ of households had kept a bird in the last 10 years. Overall, we project that 584,000 households keep almost 2 million songbirds, the category of most conservation concern. Just over half of songbirds kept are wild-caught. We identified an increase in popularity (since 1999) of three native species (long-tailed shrike Lanius schach, orange-headed thrush Zoothera citrina and whiterumped shama Copsychus malabaricus) attributable to their popularity in bird song contests. In the latter two species this has caused 'rolling' local extinctions across West Indonesia. Given the huge popularity and deep cultural significance of bird-keeping we argue that, in this case, lobbying for stricter regulation is undesirable, impractical and may alienate a potential future supporter base for bird conservation in Indonesia. We argue in favour of a portfolio of softer policy instruments that may include market-based and voluntary mechanisms and engage a wider range of people and organizations.
\end{abstract}

Keywords CITES, environmental governance, Indonesia, pet-keeping, wildlife trade.

\section{Introduction}

C dward O. Wilson proposed that humans are character$\mathrm{C}_{\text {ized by a deep affiliation with the natural world that is }}$ rooted in our biology (Wilson, 1984). One of the most obvious manifestations of these so-called biophilic attractions and positive feelings is the widespread practice of keeping pets for companionship or as objects of intrinsic beauty, curiosity and/or prestige (Erikson, 1997; Drews, 2001). This social practice is a double-edged sword for the global conservation movement. On the positive side pet-

PAUl JePson (Corresponding author) and RiChaRd J. LADle Biodiversity Research Group, School of Geography and Environment, South Parks Road, Oxford, OX1 3QY, UK. E-mail paul.jepson@ouce.ox.ac.uk

Received 20 December 2007. Revision requested 14 March 2008. Accepted 21 May 2008. keeping can be considered one of the most important ways of promoting interest and respect for the non-human world and, unlike zoological parks, allows intimate interactions with strong psychological and social benefits. Put in another way, affection and admiration for pets may also promote positive attitudes towards the continued protection of wild animals in their natural habitats.

Unfortunately, pet-keeping can also generate threats to populations of wild species. For example, recent models suggest that domestic cats Felis catus in the UK may cause decreases of urban songbird abundance of up to $90 \%$ (Beckerman et al., 2007). More relevant to the present study, consumer demand for pets taken from the wild can promote unsustainable supply chains in wildlife in countries and regions that are poorly regulated. For example, the global trade in ornamental fishes was estimated in the mid 1990s to involve c. 350 million fish annually with a combined value of > USD 900 million (Young, 1997, cited in Tissot \& Hallacher, 2003). Although the figures may be less startling for other vertebrate groups the conservation significance of the pet trade is well recognized, especially if the rarity value of a species captures the attention of so-called collectors in the west. The Spix's macaw Cyanopsitta spixii and Bali starling Leucopsar rothschildi are two infamous examples of specialist demand driving the ecological extinction of species (Juniper, 2002; Sodhi et al., 2004).

International trade in species has been well studied and has an established regulatory regime founded on CITES, employing a combination of laws, quotas, fines, trade bans, trade monitoring protocols and organization capacity building (Oldfield, 2003). In contrast, practices of pet-keeping and trade that operate within national boundaries are poorly known and governed. Where information is available the conservation implications of pet-keeping appear considerable. In Costa Rica $24 \%$ of households kept wild species as pets and parrots were the most common wild-caught pet (Drews, 2001), and in Indonesia birds are the most popular pet in urban areas and $60.2 \%$ of bird-keeping households kept a wild bird (Jepson \& Ladle, 2005). Based on the ubiquity of the pastime, non-state market-based policy instruments (cf. Cashore, 2002) may be more effective than extending the international regulation and enforcement approach into the Indonesian domestic arena (Jepson \& Ladle, 2005).

In response to this initial study we initiated a project to create a stronger evidence base from which to assess and develop alternative or complementary policy options aimed at reducing the negative conservation impacts of birdkeeping in Indonesia. The research was conducted by 
a partnership involving the Oxford University Centre for the Environment, the market research company Nielsen, the conservation group Burung (formerly BirdLife) Indonesia, and the bird keeper association Pelestari Burung Indonesia. Key features of this research include: (1) the generation of a more extensive and detailed evidence base on the sociodemographics of bird-keeping, (2) the employment of social marketing frameworks and social science techniques to generate a detailed understanding of the relationship between consumers, wildlife and policy instruments (Kotler \& Roberto, 1989), and (3) the desire to explore the notion of third generation governance mechanisms whereby the willing cooperation of those subject to governance, in our case bird keepers, is enlisted (Durant et al., 2004).

Here we present a conservation survey tool for large-scale social surveys of public attitudes and practices adapted from Nielson's household consumer surveys, and the results from the application of this tool to bird-keeping habits in six major cities of Java and Bali. We report spatial, temporal and cultural characteristics of bird-keeping within these cities, including numbers, ethnicity and socio-economic attributes of bird keepers, the species kept, the projected numbers of each species and the proportions of wild-caught and captivebred birds. Where possible, we compare the results of this survey with our earlier (1999) survey to identify general trends and dynamics in the pastime. We then discuss the results in the context of the relationship between birdkeeping and various socio-economic demographic attributes of the urban population to provide a more nuanced understanding of the objects (the species of concern) and targets (the individuals whose behaviours we seek to change) of conservation governance. Finally, we discuss the implications of the expanded evidence base for the development of new governance mechanisms.

\section{Methods}

The six cities surveyed were selected on the basis of being included in the Nielsen Omnibus survey and for which we had existing data (Jakarta and Bandung in West Java, Semarang in Central Java and Surabaya in East Java), and being large cities and known centres of bird keeping with distinct cultural heritages (Yogyakarta in Central Java and Denpasar in south Bali).

\section{Questionnaire development and piloting}

We used a face-to-face questionnaire survey of a random sample of 1,781 households. Face-to-face surveys were necessary because they support longer and more complex question sets. A random sample permitted the application of robust statistical tests and projection of results to the urban population. The six-city sample ensured adequate sampling of geographical and cultural variation.
The questionnaire comprised two sections: a group of question sets asked of all households and an additional group asked of only songbird-keeping households. A set of three initial filter questions excluded people employed in the media, advertising and research industries, assured that they had not been interviewed on the topic in the last 6 months, and asked to interview the person who made decisions about bird-keeping in the household. The first section, asked of the total sample population, consisted of three question sets: (1) Nielsen Indonesia's standard socioeconomic attribute and media habit questions, (2) petkeeping history, including birds, and (3) general attitudes to birds, nature and conservation. The well-validated Nielsen methodology asks respondents to assign themselves to: their position in the household (eight categories), main occupation (15 categories), highest educational qualification (nine categories), and monthly household income and expenditure (27 categories, condensed into five groups: A, richest, to E, poorest). The second section, asked of songbird keepers only, involved a further four question sets covering: (4) motivations for keeping birds, (5) detailed information on birds kept (species, numbers, where sourced, value), (6) attitudes to certification and captive birds, and (7) media consumption habits. Results of question sets 4, 6 and 7 are not reported here.

The questions were developed over an 8-month period (September 2005-May 2006) and informed by a range of preparatory qualitative research work. This included: indepth interviews with seven bird-breeders and hobbyists in West and Central Java (September 2005), informal interviews with $>20$ participants at a regional song contest in Surabaya (January 2005), three focus groups with a total of 30 bird keepers held in Bogor and Jakarta (February 2006), interviews with owners of four kiosks selling birds and bird-keeping equipment in West Java (April 2006), an analysis of the weekly bird-keeping newspaper Agrobis Burung (March 2005-March 2006), a review of the representations of nature in popular magazines on pets, gardening and small-holdings, and a review of questions used in two previous Omnibus surveys conducted in June 1999 (Jepson \& Ladle, 2005) and November 2005 (P. Jepson \& R.J. Ladle, unpubl. data).

The questionnaire was initially developed in English. A final draft was translated into Indonesian by the Burung (BirdLife) Indonesia team. The Indonesian draft was piloted with 40 respondents in Bogor in May 2006 and final refinements were made during field training of enumerator team leaders.

\section{Sampling frame}

We adapted the Nielsen Indonesia Omnibus survey sample frame, which randomly surveys c. 400 households in Jakarta and 300 in other cities. Data from June 1999 (Jepson 
\& Ladle, 2005) and November 2005 (P. Jepson \& R.J. Ladle, unpubl. data) Omnibus surveys placed incidence levels of bird-keeping households at between 10\% (Jakarta) and 30\% (Bandung). Based on this incidence rate it would not be possible to produce valid projections for some variables, yet enlarging the base sample would produce an unfeasibly large number of sample households. To overcome this problem we added a booster sample of bird-keeping households to meet a quota of 75 bird-keeping respondents per city, giving a total sample of 450 songbird-keeping households.

Following the Nielsen methodology the base sample was generated using the Indonesian administrative divisions of neighbourhoods (rukun tertangga), which normally contain 50 households. Official lists of neighbourhoods, which are numbered, were obtained from every kelurahan (village) in each city. Neighbourhoods were stratified geographically. Thirty neighbourhoods per city were selected randomly from the stratified list, with 10 respondents (households) sampled in each.

The protocol for choosing households within a neighbourhood was as follows: (1) the house of the neighbourhood head (ketua rukun tertangga) was identified and permission sought to survey households in that neighbourhood; (2) if permission was denied, enumerators moved to the neighbourhood numbered one higher; (3) where permission was granted, enumerators began sampling at the first to fourth house (randomly selected beforehand) on the left of the neighbourhood head's house; (4) the enumerator then sampled every third house counting only residential buildings on the left-side of the road. Each time they met a road junction they turned left; (5) if the household did not meet the criteria for inclusion in the survey (see below) the enumerator moved to the next third house (if the enumerator was unable to interview an appropriate respondent from a household after three visits, the enumerator added a replacement household following the same sampling protocol); (6) if the enumerator had sampled the entire neighbourhood and not achieved 10 respondents, the survey was extended along the road into the next neighbourhood.

For the purpose of the survey a household was defined as an economically discrete social unit whose occupants cooked together. Individuals living in rented rooms were excluded. Thus, a household did not necessarily equate to a building. To prevent over-representation of households from barrack-type (army and civil service) accommodation, a maximum of three household units were sampled from each complex. For a non-bird-keeping household the respondent was the head of the household or, in their absence, another adult who could answer questions on household socio-attributes. For songbird-keeping households the respondent had to be the person who made decisions about bird-keeping in the household (to exclude children and household help).
The booster sample was generated by counting the songbird keepers in the randomized neighbourhood sample (above) and then calculating the number of additional respondents required to achieve our desired sample size of 75 bird-keeping households per city. The number of additional neighbourhoods in which the booster respondents were to be found was calculated by dividing the booster sample needed per city by the average frequency of bird keepers in the randomized neighbourhood sample. This generated a number of new neighbourhoods to be sampled together with a target number of songbird-keeping households to survey within each. Following this method cities with a low frequency of songbird-keeping households would require a large booster sample and a prohibitive number of additional neighbourhoods to be sampled. To overcome this an arbitrary number of 10 additional neighbourhoods was set. Booster neighbourhoods were selected on the basis that they represented the geographical spread of the city and were not located in a city sub-district that had been previously surveyed. Songbird keepers were located through observation and enquiry.

\section{Survey administration}

Questionnaires were administered in an informal setting in the respondent's house. Enumerators were trained to ensure that other members of the household did not contribute. Permission to implement the survey was sought by the team leader directly from the neighbourhood head, using a letter prepared for the purpose by Burung Indonesia and Pelestari Burung Indonesia. Where the neighbourhood head requested, permission was sought from the head of the subdistrict (the next highest administrative division).

Two survey teams were established in each city. The 12 team leaders underwent a 3-day training course at Nielsen's training centre, covering project objectives and survey team management in addition to field tests and implementation of the questionnaire. Each team leader recruited a team of 4-6 enumerators who were then trained by the team leader and Burung Indonesia project supervisor.

Implementation of the survey took 2-6 weeks in JuneJuly 2006, depending on the time availability of enumerators, the size of the city, and receptivity of respondents. During the surveys, teams regularly met to resolve arising issues. Quality and integrity of questionnaire data were assured by the team leader observing the administration of the first questionnaire by each enumerator and continuing to do so until satisfied that the enumerator was competent to work alone, and undertaking a recall of $30 \%$ of the total questionnaires submitted by each enumerator throughout the survey period. Recall involved contacting the respondent by phone or visiting to confirm that they had been interviewed and checking consistency of answers by repeating 3-5 randomly selected questions. Questionnaires 
directly observed during the witnessing were counted towards the $30 \%$ recall quota.

\section{Data management and analysis}

All questionnaires received by Burung Indonesia were given a unique code number and checked for completeness and consistency of answers to key questions. Data input into spreadsheets was carried out in the Burung Indonesia offices by a team of six volunteers recruited specifically for the task. The data entry teams worked in 4-hour shifts to avoid mistakes because of tiredness. As a safeguard against data entry errors $10 \%$ of questionnaires processed by each volunteer were rechecked by an independent team.

We classed respondents into hobbyist and pet bird keepers. Hobbyists were defined on the basis of showing a bird at a song contest. To minimize the variance in our projections we calculated the average number of birds per bird-keeping household from the dedicated survey, i.e. songbird-keeping households within the random sample plus all booster sample households $(n=454)$.

\section{Projections}

Because of the rigorous and representative nature of the sample it was possible to make accurate projections of both the number of bird-keeping and songbird-keeping households for the study populations and, more cautiously, the total number of songbirds of different species currently in captivity in these cities. To render these projections more useful for policy and conservation purposes, 95\% confidence limits were calculated assuming a Poisson distribution. The projected total population size of captive songbirds in the six cities was calculated by multiplying the projected number of songbird-keeping households (random sample) by the mean number of songbirds per songbird keeper (random plus booster sample). Population estimates for individual species were calculated by multiplying the total captive songbird number by the frequency of each species in the whole sample (random plus booster).

\section{Results}

\section{Incidence of bird-keeping}

The survey found that birds were the most popular pet, with $35.7 \%$ of households keeping a bird in the six cities surveyed. Fish were the next most popular pet, followed by cats, dogs, small mammals, livestock, reptiles and monkeys (Fig. 1a). Of households keeping different bird types, dove was the most popular category followed by songbird, showchickens, pigeon and exotics (high value rarely-kept species favoured by collectors, such as macaws Ara spp., green peafowl Pavo muticus and hill myna Gracula religiosa;
Fig. 1b). Within our sample population $57.6 \%(1,025 / 1,781)$ of households had kept a bird previously (in the last 10 years) and $27.7 \%(494 / 1,781)$ had kept a songbird. There were significant differences in the proportions of households in the sample population keeping birds in different cities (Table 1).

Of the households surveyed $20 \%(357 / 1,781)$ had ceased to keep birds within the last 10 years, and of those who reported the year they stopped $66.9 \%$ (234/350) ceased birdkeeping within 3 years of obtaining a bird. During 20002006 the percentage of households giving up birds was between $1.8 \%$ (2004) and $2.5 \%$ (2000) with the exception of 2005 (the year of bird flu scares) when the rate of giving up doubled to $4.4 \%$.

\section{Numbers of birds}

The projected number of households across the six cities keeping a bird (excluding chicken) was 1,451,803 (95\% CI $1,188,812-1,747,554)$. Jakarta and Surabaya held the highest number of bird-keeping households (Table 2). Based on the mean number of songbirds kept per songbird keeper (random plus booster sample) and stratified by city, the projected number of songbirds kept throughout the six cities was 2,157,754 (Table 2).

According to the dedicated survey, of this total number of songbirds kept $31.8 \%$ were domestic species, $58.5 \%$ (c. 1 million birds) were wild-caught species, $1.6 \%$ were species that are now mostly captive-bred, and $8.1 \%$ were species for which some captive breeding occurs. The figures for the wild-caught category were then further subdivided into wild-caught native species $(94.9 \%)$ and wild-caught imported species, mostly from China (5.1\%). These latter two figures are not comparable to those reported for these categories in Jepson \& Ladle (2005).

Restricting analysis to the four Javan cities common to both surveys allowed further investigation of the data. Applying the same methods of projection (average number of birds kept per household in the random sample) we discovered that the number of wild-caught native songbirds kept has increased (projection $=738,518$ in 1999 cf. 1,086,692 in 2006) and the number of wild-caught imported songbirds has substantially decreased (projection $=189,210$ in $1996 \mathrm{cf} .58,400$ in 2006). For five popular songbird species, we found a strong and consistent pattern of increasing ownership (Table 3).

Thirty-five bird species were recorded in the survey, of which 29 were included in the analysis $(n \geq 5)$. In terms of numbers and proportion of households the most popular was the canary Serinus canarius, followed by three native species: long-tailed shrike Lanius schach, orange-headed thrush Zoothera citrina and white-rumped shama Copsychus malabaricus. These, together with two common garden bulbuls Pycnonotus spp., had projected captive populations 

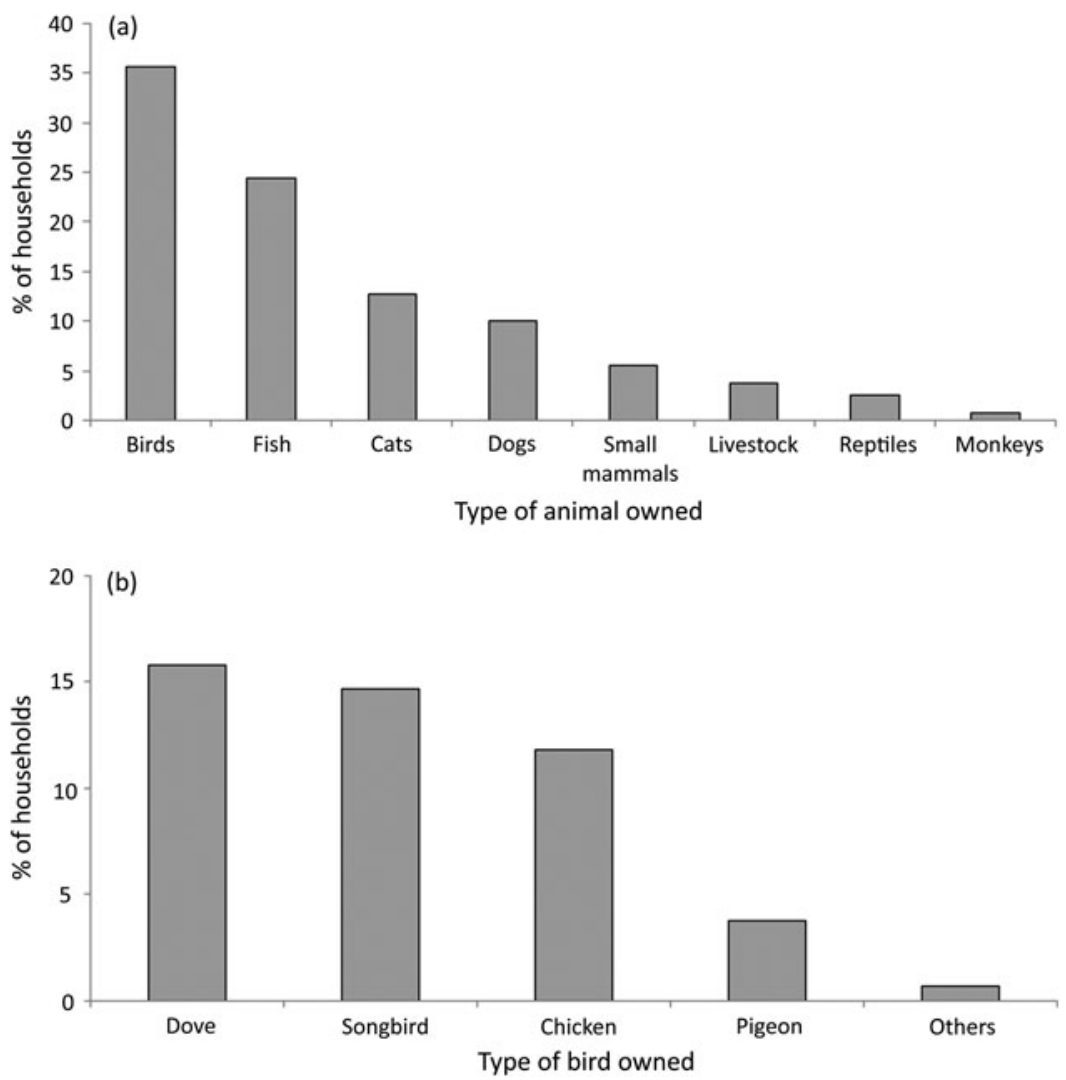

FIG. 1 Percentages of households in six cities on Java and Bali keeping (a) different categories of pet and (b) different categories of bird.

in the six cities of $>100,000$ birds. Five further species had projected captive populations $>50,000$, of which three (lovebird Agapornis spp., budgerigar Melopsittacus undulatus and Java sparrow Padda oryzivora) are captive-bred in Java (Tables 4 \& 5 ).

Three species of birds recorded in our survey are listed in CITES Appendices I \& II. These are straw-headed bulbul Pycnonotus zeylanicus, Java sparrow and hill myna, and together have a captive population of $100,003(5.4 \%$ of the total captive population). Java sparrow is commonly bred and the total for the other two species was 50,001 (2.7\%). The comparable figures for species categorized as threatened by BirdLife International (2001; species as above with the addition of lory Lorius spp.) were 105,558 (5.7\%), or 55,557 (3.0\%) if Java sparrow was excluded, and for those protected under Indonesian law (Java sparrow and blackwinged starling Sturnus melanopterus) were 61,111 (3.3\%). No songbird keepers surveyed currently kept a cockatoo

TABLE 1 Percentages (and number) of households keeping birds in 2006 and at some time in the previous 10 years in six cities on Java and Bali, with $\chi^{2}$ tests between cities for each bird type and time. Data calculated from random household survey $(\mathrm{n}=1,781)$.

\begin{tabular}{|c|c|c|c|c|c|c|c|c|c|}
\hline Type & $\begin{array}{l}\text { Time- } \\
\text { frame }^{1}\end{array}$ & $\begin{array}{l}\text { Jakarta } \\
(\mathrm{n}=293)\end{array}$ & $\begin{array}{l}\text { Bandung } \\
(\mathrm{n}=299)\end{array}$ & $\begin{array}{l}\text { Yogyakarta } \\
(\mathrm{n}=300)\end{array}$ & $\begin{array}{l}\text { Semerang } \\
(\mathrm{n}=299)\end{array}$ & $\begin{array}{l}\text { Surabaya } \\
(\mathrm{n}=290)\end{array}$ & $\begin{array}{l}\text { Denpasar } \\
(\mathrm{n}=300)\end{array}$ & $\chi^{2}$ & $\mathrm{P}$ \\
\hline \multirow[t]{2}{*}{ Dove } & $\mathrm{C}$ & $8.2 \%(24)$ & $11.0 \%(33)$ & $15 \%(45)$ & $16.4 \%(49)$ & $16.6 \%(48)$ & $27.7 \%(83)$ & 49.86 & $<0.001$ \\
\hline & $\mathrm{P}$ & $17.7 \%(52)$ & $19.1 \%(57)$ & $26.7 \%(80)$ & $31.1 \%(93)$ & $28.6 \%(83)$ & $39.3 \%(118)$ & 48.25 & $<0.001$ \\
\hline \multirow[t]{2}{*}{ Songbird } & $\mathrm{C}$ & $8.9 \%(26)$ & $8.4 \%(25)$ & $14.7 \%(44)$ & $19.1 \%(57)$ & $20.0 \%(58)$ & $17.3 \%(52)$ & 28.77 & $<0.001$ \\
\hline & $\mathrm{P}$ & $19.5 \%(57)$ & $18.7 \%(56)$ & 34.7 (104) & $34.8 \%(104)$ & $31.7 \%(92)$ & $27.0 \%(81)$ & 39.11 & $<0.001$ \\
\hline \multirow[t]{2}{*}{ Chicken } & $\mathrm{C}$ & $12 / 3 \%(36)$ & $6.7 \%(20)$ & $12.0 \%(36)$ & $9.7 \%(29)$ & $9.7(28)$ & $20.7(62)$ & 32.68 & $<0.001$ \\
\hline & $\mathrm{P}$ & $25.3 \%(74)$ & $19.1 \%(57)$ & $28.0 \%(84)$ & $21.7 \%(65)$ & $17.6 \%(51)$ & $26.3 \%(79)$ & 14.63 & 0.012 \\
\hline \multirow[t]{2}{*}{ Pigeon } & $\mathrm{C}$ & $2.0 \%(6)$ & $5.7 \%(17)$ & $5.3 \%(16)$ & $2.3 \%(7)$ & $6.2 \%(18)$ & $1.0(3)$ & 20.25 & 0.001 \\
\hline & $\mathrm{P}$ & $5.8 \%(17)$ & $15.1 \%(45)$ & $12.7 \%(38)$ & $12.4(37)$ & $11.7 \%(34)$ & $3.7(11)$ & 32.07 & $<0.001$ \\
\hline \multirow[t]{2}{*}{ Exotic $^{2}$} & $\mathrm{C}$ & $0.3 \%(1)$ & $0.3 \%(1)$ & $0.3 \%(1)$ & $0.7 \%(2)$ & $0.7 \%(2)$ & $1.7 \%(5)$ & & \\
\hline & $\mathrm{P}$ & $0.7 \%(2)$ & $0.7 \%(2)$ & $1.3 \%(4 / 300)$ & $1.7 \%(5)$ & $1.0(3)$ & $2.3 \%(7)$ & & \\
\hline \multirow[t]{2}{*}{ Total } & $\mathrm{C}$ & $25.3 \%(74)$ & $25.4 \%(76)$ & $35.8 \%(107)$ & $38.4(113)$ & $40.6 \%(117)$ & $48.2 \%(144)$ & 51.97 & $<0.001$ \\
\hline & $\mathrm{P}$ & $50.2 \%(147)$ & $49.5 \%(148)$ & $59.0 \%(177)$ & $62.9 \%(188)$ & $60.0 \%(174)$ & $63.7 \%(191)$ & 23.50 & $<0.001$ \\
\hline
\end{tabular}

${ }^{1} \mathrm{C}$, currently owned; $\mathrm{P}$, current plus previously owned

${ }^{2}$ Numbers of exotics were too low for statistical analysis 


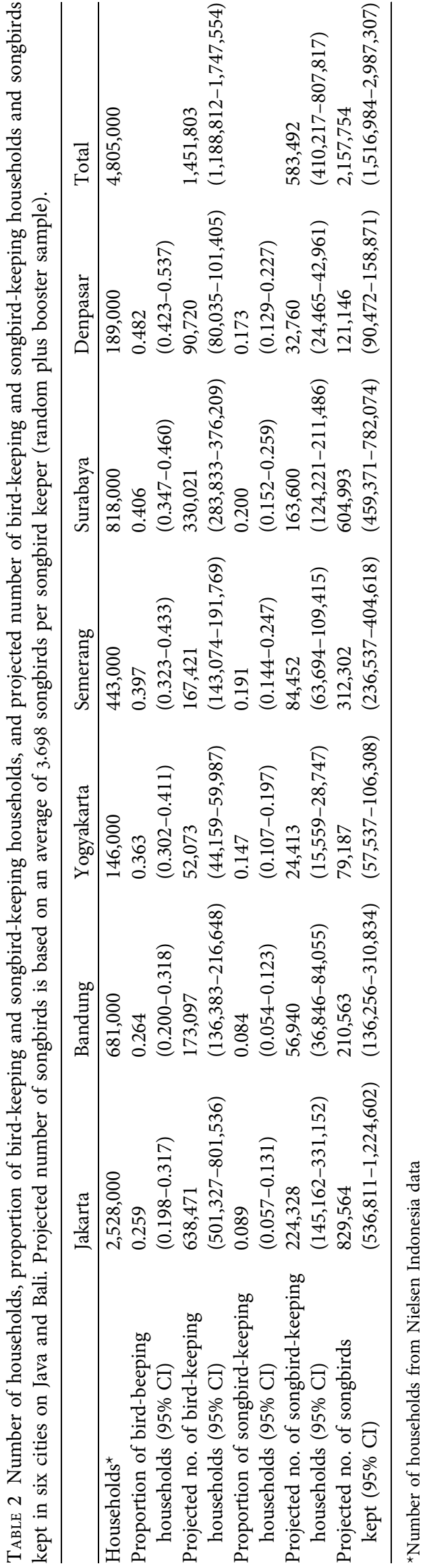

Cacatua spp., which are included in all of the above three categories.

Comparison of the incidence of keeping of certain key species with our earlier survey $(n=1,740$; Jepson \& Ladle, 2005) revealed some marked increases for some species of conservation concern In the 1999 survey orange-headed thrush was only detected in three households (all in Bandung) whereas in this 2006 survey it was detected in 14 households in Bandung, Surabaya and Semerang (four Javan cities, random sample); long-tailed shrike was detected in one household in Surabaya in 1999 but in 38 households and all four cities, although predominately in Surabaya and Semerang, in 2006; white-rumped shama was detected in 13 households in 1996 but in 25 households in 2006. Leafbird Chloropsis spp. was undetected in 1999 but found in 12 households in Surabaya, Semerang and Bandung in 2006. Straw-headed bulbul was detected in 11 households in 1999 and 10 in 2006.

\section{Socio-demographic associations}

Our sample included seven distinct ethnicities, although three of these accounted for $83.5 \%$ of the sample population: Javanese (54.8\%), Sundanese (16.2\%) and Balinese (12.5\%). Restricting our analysis to these three ethnicities, we found a significant difference in the incidence of birdkeeping $\left(\chi^{2}=41.093, \mathrm{df}=2, \mathrm{P}<0.001\right)$ and of keeping doves $\left(\chi^{2}=11.065, \mathrm{df}=2, \mathrm{P}=0.003\right)$, zebra doves Geopelia striata $\left(\chi^{2}=32.75, \mathrm{df}=2, \mathrm{P}<0.001\right)$, songbirds $\left(\chi^{2}=8.68\right.$, $\mathrm{df}=2, \mathrm{P}=0.013)$ and chickens $\left(\chi^{2}=37.001, \mathrm{df}=2, \mathrm{P}<\right.$ o.001). In all these cases the incidence of bird-keeping was highest amongst the Balinese and lowest amongst the Sundanese. Songbird-keeping showed the least differentiation between Balinese and Javanese populations.

Household income was not significantly associated with bird-keeping or category of bird kept. An exception to this general pattern occurred with chicken-keeping, where lower income group (C \& D) households were more likely to keep a chicken $\left(\chi^{2}=14.029, \mathrm{df}=4, \mathrm{P}=0.007\right)$. The head of household's occupational type was significantly associated with bird-keeping $\left(\chi^{2}=11.15, \mathrm{df}=3, \mathrm{P}=0.011\right)$ in general as well as, more specifically, the owning of doves $\left(\chi^{2}=8.61, \mathrm{df}=3, \mathrm{P}=0.035\right)$ and songbirds $\left(\chi^{2}=13.13\right.$, $\mathrm{df}=3, \mathrm{P}=0.004)$. Blue collar and non-workers were more likely to keep a bird, with blue-collar workers more likely to keep a songbird and non-workers showing most preference for doves.

We found a weak but significant association between educational level and bird-keeping $\left(\chi^{2}=9.63, \mathrm{df}=4, \mathrm{P}=\right.$ 0.022) with respondents in possession of a diploma or degree being less likely to own a bird. However we found no association between education and the categories of birds kept. The two oldest age categories displayed the highest incidence of bird-keeping but the youngest age group $(<25$ 
TABLE 3 Number (and \%) of households keeping songbird species that competed in bird song contests in 1999 and 2006 in four cities on Java and Bali. Figures are from random households surveys.

\begin{tabular}{|c|c|c|c|c|c|c|c|c|}
\hline & \multicolumn{2}{|l|}{ Jakarta } & \multicolumn{2}{|l|}{ Bandung } & \multicolumn{2}{|l|}{ Semarang } & \multicolumn{2}{|l|}{ Surabaya } \\
\hline & $\begin{array}{l}1999 \\
(\mathrm{n}=520)\end{array}$ & $\begin{array}{l}2006 \\
(\mathrm{n}=293)\end{array}$ & $\begin{array}{l}1999 \\
(\mathrm{n}=309)\end{array}$ & $\begin{array}{l}2006 \\
(\mathrm{n}=299)\end{array}$ & $\begin{array}{l}1999 \\
(\mathrm{n}=305)\end{array}$ & $\begin{array}{l}2006 \\
(\mathrm{n}=299)\end{array}$ & $\begin{array}{l}1999 \\
(\mathrm{n}=302)\end{array}$ & $\begin{array}{l}2006 \\
(\mathrm{n}=290)\end{array}$ \\
\hline $\begin{array}{l}\text { Long-tailed shrike } \\
\text { Lanius schach }\end{array}$ & 0 & $3(1.0)$ & 0 & $1(0.3)$ & 0 & $15(5.0)$ & $1(0.3)$ & $19(6.6)$ \\
\hline $\begin{array}{l}\text { Orange-headed thrush } \\
\text { Zoothera citrine }\end{array}$ & 0 & 0 & $3(1.0)$ & $4(1.3)$ & 0 & $5(1.7)$ & 0 & $5(1.7)$ \\
\hline $\begin{array}{l}\text { White-rumped shama } \\
\text { Copsychus malabaricus }\end{array}$ & $2(0.4)$ & $3(1.0)$ & $2(0.6)$ & $6(2.0)$ & $7(2.3)$ & $10(3.3)$ & $2(0.7)$ & $6(2.1)$ \\
\hline $\begin{array}{l}\text { Magpie robin Copsychus } \\
\text { saularis }\end{array}$ & 0 & 0 & 0 & $1(0.3)$ & $5(1.6)$ & $12(4.0)$ & $5(1.7)$ & $5(1.7)$ \\
\hline Leafbirds Chloropsis spp & 0 & 0 & 0 & $3(1.0)$ & 0 & $4(1.3)$ & 0 & $5(1.7)$ \\
\hline
\end{tabular}

years old) kept more birds. Pigeons were more likely to be owned by those $<25$ years of age (Table 6 ).

Based on the dedicated survey, we found significant associations between certain socio-demographic attributes and ownership of the eight commonest species of songbird. More than twice as many Sundanese kept a canary than any other ethnicity $\left(\chi^{2}=52.56, \mathrm{df}=2, \mathrm{P}<0.001\right)$. Higher education categories were more likely to keep a canary $\left(\chi^{2}=9.88, \mathrm{df}=3, \mathrm{P}=0.002\right)$ and blue-collar workers were less likely to keep this type of bird than other employment categories $\left(\chi^{2}=14.69, \mathrm{df}=3, \mathrm{P}=0.002\right)$.

Orange-headed thrush was more common in Sundanese households $\left(\chi^{2}=12.95, \mathrm{df}=2, \mathrm{P}=0.002\right)$, and the incidence of keeping this thrush displayed a consistent pattern of increase from the lowest income category, E, $(5.7 \%)$ to the highest income category, A, $\left(20.0 \% ; \chi^{2}=10.01, \mathrm{df}=4\right.$, $\mathrm{P}=0.04)$. Entrepreneurial and white-collar workers appeared more likely to keep an orange-headed thrush $\left(\chi^{2}=13.13, \mathrm{df}=3, \mathrm{P}=0.004\right)$ and this bird species was less commonly kept by individuals who had not completed high-school $\left(\chi^{2}=8.24, \mathrm{df}=3, \mathrm{P}=0.041\right)$.

Long-tailed shrike was more popular with Javanese $\left(\chi^{2}=6.43, \mathrm{df}=2, \mathrm{P}=0.004\right)$ and much less likely to be kept by non-workers $\left(\chi^{2}=11.91, \mathrm{df}=3, \mathrm{P}=0.008\right)$. Whiterumped shama proved unpopular with Balinese $\left(\chi^{2}=13.25\right.$, $\mathrm{df}=2, \mathrm{P}=0.001)$ and was more likely to be owned by income categories $\mathrm{A}-\mathrm{C}\left(\chi^{2}=11.61, \mathrm{df}=4, \mathrm{P}=0.02\right)$. Magpie robin Copsychus spp. was predominantly owned by those in the 36-45 year old age category $\left(\chi^{2}=12.49, \mathrm{df}=4\right.$, $\mathrm{P}=0.014)$ and more highly educated people $\left(\chi^{2}=9.29\right.$, $\mathrm{df}=3, \mathrm{P}=0.026$ ).

Yellow-vented bulbul Pycnonotus goiaver was more commonly kept by the Sundanese $\left(\chi^{2}=17.09, \mathrm{df}=2, \mathrm{P}<0.001\right)$. People of this ethnicity were also more likely to own a captive-bred bird $(65.8 \%$ keeping a captive-bred bird but canaries are popular with this group; $\chi^{2}=30.38, \mathrm{df}=2$, $\mathrm{P}>0.000$ ). We found no associations between leafbird or yellow-vented bulbul ownership and socio-demographic categories but sooty-headed bulbul Pycnonotus aurigaster demonstrated a consistent association with education attainment level: from university graduates (11.3\% ownership) to primary school education or less (30.5\% ownership; $\chi^{2}=10.27, \mathrm{df}=3, \mathrm{P}=0.016$ ).

\section{Discussion}

Dedicated surveys of consumers offer a valuable additional conservation tool to assess and monitor human impacts on wild animal populations. Omnibus surveys, such as that employed in our previous study (Jepson \& Ladle, 2005), are suitable for measuring broad categories (e.g. bird type) or common activities in the population (e.g. shopping or voting preferences) but are not as suitable for detecting less common activities and/or commodities. In many developing countries assessing the status of species in situ is difficult because of the challenges of recruiting and/or training field ecologists, the reliability of statistical extrapolations and logistical issues. To date market surveys of species have been the principal means of assessing the impact of trade but data from such surveys cannot be projected or compared because it is not possible to standardize sampling. In contrast, consumer surveys can be designed following tested principles and protocols, enumerators can be trained easily, data can be verified, and the survey can be administered within a fixed time and to a designated schedule. In addition, consumer surveys can be designed to generate data that can inform and design policy and social change strategies. Moreover, consumer surveys are relatively inexpensive. The survey reported here cost c. EUR 10,000 to administer, including data entry and checking. The questionnaire development, design and basic analysis were more expensive (because of the involvement of western-located conservationists) but did not exceed EUR 12,000. As such surveys become more commonly used, and as common questions, standard question sets and analytical techniques emerge, these latter costs may fall. 
TAвLE 4 Individual bird species kept by songbird keepers in six cities on Java and Bali, ranked by popularity (random + dedicated sample), with threat status, breeding status, popularity in songbird contests, the actual number of households keeping the species and the number of individual birds recorded in our sample of 450 bird-keeping households, and the projected number of birds kept in the six cities.

\begin{tabular}{|c|c|c|c|c|c|c|}
\hline Species $^{1}$ & $\begin{array}{l}\text { Threat } \\
\text { status }^{1}\end{array}$ & $\begin{array}{l}\text { Breeding } \\
\text { status }^{2}\end{array}$ & $\begin{array}{l}\text { Song- } \\
\text { contest }^{3}\end{array}$ & $\begin{array}{l}\text { No. of } \\
\text { bird-keeping } \\
\text { households }\end{array}$ & $\begin{array}{l}\text { No. of } \\
\text { birds }\end{array}$ & $\begin{array}{l}\text { Projected no. of } \\
\text { birds }(95 \% \mathrm{CI})\end{array}$ \\
\hline Canary Serinus canarius & & $\mathrm{D}$ & $* *$ & 125 & 382 & $493,570(346,999-683,324)$ \\
\hline Long-tailed shrike & & $\mathrm{W}$ & $* * *$ & 108 & 154 & $198,979(139,890-275,476)$ \\
\hline Orange-headed thrush & & $\mathrm{W}$ & $* * *$ & 63 & 138 & $178,305(125,356-246,855)$ \\
\hline Yellow-vented bulbul Pycnonotus goiaver & & $\mathrm{W}$ & & 109 & 137 & $177,013(124,447-245,067)$ \\
\hline Sooty-headed bulbul Pycnonotus aurigaster & & $\mathrm{W}$ & & 102 & 132 & $170,553(119,905-236,122)$ \\
\hline White-rumped shama & & S & $* * *$ & 68 & 94 & $121,454(85,387-168,148)$ \\
\hline Magpie robin & & $\mathrm{W}$ & $* *$ & 63 & 77 & $99,489(69,945-137,738)$ \\
\hline Lovebird Agapornis spp. & & $\mathrm{D}$ & * & 30 & 60 & $77,524(54,502-107,328)$ \\
\hline Leafbirds & & $\mathrm{W}$ & ** & 49 & 56 & $72,356(50,869-100,173)$ \\
\hline Budgerigar Melopsittacus undulatus & & $\mathrm{D}$ & & 18 & 46 & $59,435(41,785-82,285)$ \\
\hline Java sparrow Padda oryzivora & II/VU & M & & 12 & 45 & $58,143(40,877-80,496)$ \\
\hline White-vented myna Acridotheres javanicus & & $\mathrm{W}$ & & 33 & 42 & $54,267(38,152-75,130)$ \\
\hline Common tailorbird Orthotomus sutoris & & $\mathrm{W}$ & & 25 & 39 & $50,391(35,427-69,763)$ \\
\hline Singing bush-lark Mirafra javanica & & $\mathrm{W}$ & ** & 21 & 34 & $43,930(30,885-60,819)$ \\
\hline Bar-winged prinia Prinia familiaris & & $\mathrm{W}$ & & 17 & 33 & $42,638(29,976-59,031)$ \\
\hline Chestnut-headed thrush Zoothera interpres & & $\mathrm{W}$ & ** & 18 & 32 & $41,346(29,068-57,242)$ \\
\hline Puff-throated bulbul Criniger bres & & $\mathrm{W}$ & M & 25 & 30 & $38,762(27,251-53,664)$ \\
\hline Blue flycatcher Cyornis spp. & & $\mathrm{W}$ & * & 20 & 22 & $28,426(19,984-39,354)$ \\
\hline Straw-headed bulbul Pycnonotus zeylanicus & II/VU & M & ** & 15 & 21 & $27,133(19,076-37,565)$ \\
\hline Pied starling Sturnus contra & & M & M & 11 & 15 & $19,381(13,626-26,832)$ \\
\hline Hwa mei Garrulax canorus & & $\mathrm{W}$ & ** & 8 & 15 & $19,381(13,626-26,832)$ \\
\hline White-eye Zosterops spp. & & $\mathrm{W}$ & & 7 & 14 & $18,089(12,717-25,043)$ \\
\hline Munia Lonchura spp. & & $\mathrm{W}$ & & 7 & 13 & $16,797(11,809-23,254)$ \\
\hline Black-naped oriole Oriolus chinensis & & $\mathrm{W}$ & & 10 & 10 & $12,921(9,084-17,888)$ \\
\hline Black-throated laughing thrush Garrulax chinesis & & $\mathrm{W}$ & ** & 10 & 10 & $12,921(9,084-17,888)$ \\
\hline Black-winged starling Sternus melanopterus & & S & & 9 & 10 & $12,921(9,084-17,888)$ \\
\hline Pied stonechat Saxicola caprata & & $\mathrm{W}$ & $* * *$ & 3 & 5 & $6,460(4,542-8,944)$ \\
\hline Red-billed leothrix Leothrix lutea & & $\mathrm{W}$ & & 2 & 2 & $2,584(1,817-3,578)$ \\
\hline Weaver Ploeceus spp. & & $\mathrm{W}$ & & 2 & 2 & $2,584(1,817-3,5768)$ \\
\hline
\end{tabular}

${ }^{1}$ II, CITES Appendix II; VU, Vulnerable (IUCN, 2008)

${ }^{2} \mathrm{D}$, domesticated and widely bred in Indonesia; $\mathrm{M}$, mostly captive bred in Indonesia but some wild-caught; S, some captive-breeding but mostly wildcaught; W, wild-caught, very limited or experimental breeding

${ }^{* * *}$, prestigious species to compete at songbird contests; ${ }^{* *}$, species competed at songbird-contests but less popular and prestigious; ${ }^{\star}$, least popular competition species; $\mathrm{M}$, used to train other species entered in songbird contests

Indonesia currently relies on a traditional state-led lawand-fine approach to regulating the trade or harvest of species. Species recognized by the state as being threatened because of exploitation or other factors are included on Indonesia's list of protected species; it is an offence to harvest, own or trade these species and the government is responsible for identifying and prosecuting offenders (Republic of Indonesia, 1999). Bird conservation organizations play an important role in this process by identifying threatened species and lobbying for their inclusion on this list.

It is clear that some species are widely kept and that this is having conservation impacts. The data reported herein may partly explain the marked decline in wild bird populations observed over the last 50 years (Holmes, 1995). Of our list of the 29 most commonly owned species
(Table 4), only three have any form of regulatory protection (two CITES Appendix II; CITES, 2008), and two are on the IUCN Red List (IUCN, 2008; two Indonesian protected species). A further four species, listed under 'other' and reclassified as 'exotics' were IUCN Red List and/or protected species. Based on this finding it could be surmised that bird-keeping is not a serious conservation issue. However, these figures merely expose the time lag between the emergence of threats to wild species and the subsequent codification of these into relevant frameworks and legislation.

A comparison between this present investigation and our 1999 survey indicates that the number of native songbirds kept is increasing and the number of imported songbirds (mainly Garrulax and Lirhtorix spp. from China) has substantially decreased. This can be partly explained by 
TABLE 5 Percentages of songbird-keeping households in six cities on Java and Bali keeping the eight most common songbird species.

\begin{tabular}{|c|c|c|c|c|c|c|c|c|}
\hline Species & $\begin{array}{l}\text { Jakarta } \\
(\mathrm{n}=70)\end{array}$ & $\begin{array}{l}\text { Bandung } \\
(\mathrm{n}=78)\end{array}$ & $\begin{array}{l}\text { Yogyakarta } \\
(\mathrm{n}=78)\end{array}$ & $\begin{array}{l}\text { Semerang } \\
(\mathrm{n}=73)\end{array}$ & $\begin{array}{l}\text { Surabaya } \\
(\mathrm{n}=71)\end{array}$ & $\begin{array}{l}\text { Denpasar } \\
(\mathrm{n}=74)\end{array}$ & $\chi^{2}$ & $\mathrm{P}$ \\
\hline Canary & $14.3(10)$ & $67.9(53)$ & $30.8(24)$ & $28.8(21)$ & $22.5(16)$ & 16.2.(12) & 69.47 & $<0.001$ \\
\hline Long-tailed shrike & $20.0(14)$ & $17.9(14)$ & $25.6(20)$ & $39.7(29)$ & $40.8(29)$ & $21.6(16)$ & 18.79 & $=0.002$ \\
\hline Orange-headed thrush & $14.3(10)$ & $30.8(24)$ & $12.8(10)$ & $17.8(13)$ & $11.3(8)$ & $12.2(9)$ & 14.93 & $=0.011$ \\
\hline Yellow-vented bulbul & $22.9(16)$ & $12.8(10)$ & $43.6(34)$ & $35.6(26)$ & $19.7(14)$ & $21.6(16)$ & 25.56 & $<0.001$ \\
\hline Sooty-headed bulbul & $24.3(24)$ & $23.1(18)$ & $17.9(14)$ & $35.6(26)$ & $16.9(12)$ & $23.0(17)$ & 12.48 & $=0.029$ \\
\hline White-rumped shama & $17.1(12)$ & $26.9(21)$ & $20.5(16)$ & $24.7(18)$ & $14.1(10)$ & $2.7(2)$ & 19.40 & $=0.002$ \\
\hline Magpie robin & $22.9(16)$ & $14.1(11)$ & $20.5(16)$ & $26.0(19)$ & $11.3(8)$ & $8.1(6)$ & 12.79 & $=0.025$ \\
\hline Leafbirds & $15.7(11)$ & $12.8(10)$ & $10.3(8)$ & $20.5(15)$ & $11.3(8)$ & $12.2(9)$ & 4.46 & $=0.485$ \\
\hline
\end{tabular}

the sharp rises in price of imported songbirds following the collapse of the Indonesia rupiah in 1997, closely followed by Indonesia banning the importation of Chinese songbirds in 2001 because of concerns over avian flu. The keeping of native species with exceptional vocal capacities (the two Zoothera thrushes, long-tailed shrike, white-rumped shama, magpie robin and leafbirds) appears to have increased dramatically in the last 5-10 years. These are principally territorial species with correspondingly limited populations, and the scale of exploitation suggests significant negative impacts on wild populations. In Indonesia the strawheaded bulbul, a traditional favourite, is already virtually extinct in the wild because of high demand from bird keepers (BirdLife International, 2001). The hobbyist newspaper editor and bird breeders interviewed believed that wild populations of several species have been decimated in the last 5 years as a direct result of their rise in popularity amongst bird keepers. In the case of orange-headed and chestnut-headed thrushes Zoothera citrine and Zoothera interpres, the newspaper editor recounted how each forest block in Java was systematically 'caught out' by 2003 or 2004. Java was an important population centre for both species, each of which was relatively common. Orangeheaded thrush has a wide but disjunct distribution in Asia and is rare outside Java and Bali, and the chestnut-headed thrush occupies a more restricted distribution from East Java into the Lesser Sundas (Hoyo et al., 2005).

It appears that white-rumped shama was 'caught out' from Java prior to 1997 but the fall of the Suharto regime in 1998 and the subsequent rise of illegal logging and agricultural encroachment in Sumatra and Kalimantan has created new supplies of wild-caught birds. This has decimated populations in south-west and northern Sumatra (N. Brickle \& C. Shephard, pers. comms) and West Kalimantan (Y. Kurniawan, pers. comm.), and this pattern may be repeated across western Indonesia.

The data suggest that market demand for species in Java and Bali is dynamic and influenced by fashions in songbird contests, broader social economic trends, and legislation. This poses a significant challenge to legislation-based instruments, namely remaining responsive to variation in market demand (regulatory lag) while avoiding shifting the focus of exploitation from one species to another. For instance, adding orange-headed thrush to a protected species list may simply generate more interest in currently less popular song contest species such as leafbirds, thereby displacing rather than solving the conservation problem.

Law and enforcement approaches could be expected to be more effective when the legislation targets a small or specific group within the population (e.g. criminals) or intuitively makes some sense on safety, moral or other grounds (e.g. driving whilst using a mobile phone). Our finding that two thirds of urban households have kept a bird in the last 10 years, and that bird-keeping is not strongly correlated with any age, income, professional or ethnic group, underlines the ubiquitous nature of the pastime and suggests that tighter regulation would be opposed by public opinion and receive little support from government enforcement bodies, not least because many officials are bird keepers. Furthermore, the practice of bird-keeping, and in particular competing songbirds, brings together people from all social backgrounds in a common interest. As such, bird-keeping may

TABLE 6 Percentages of five age groups keeping birds in six cities on Java and Bali, with $\chi^{2}$ tests for differences between age groups.

\begin{tabular}{|c|c|c|c|c|c|c|c|}
\hline Species & $\begin{array}{l}<25 \text { years } \\
(\mathrm{n}=223)\end{array}$ & $\begin{array}{l}26-35 \text { years } \\
(\mathrm{n}=404)\end{array}$ & $\begin{array}{l}36-45 \text { years } \\
(\mathrm{n}=474)\end{array}$ & $\begin{array}{l}46-65 \text { years } \\
(\mathrm{n}=552)\end{array}$ & $\begin{array}{l}>65 \text { years } \\
(\mathrm{n}=86)\end{array}$ & $\chi^{2}$ & $\mathrm{P}$ \\
\hline$\overline{\text { Pigeon }}$ & 8.1 & 4.0 & 3.0 & 3.1 & 1.2 & 14.53 & 0.011 \\
\hline Dove & 6.3 & 4.0 & 5.9 & 9.6 & 19.8 & 32.18 & $<0.001$ \\
\hline Zebra dove & 9.0 & 6.7 & 10.1 & 13.6 & 15.1 & 14.41 & 0.006 \\
\hline Songbird & 14.8 & 13.9 & 13.9 & 17.8 & 9.3 & 6.32 & 0.177 \\
\hline Chicken & 12.6 & 13.6 & 11.2 & 10.5 & 18.6 & 6.04 & 0.196 \\
\hline All & 36.2 & 33.3 & 32.8 & 41.0 & 46.5 & 13.14 & 0.011 \\
\hline
\end{tabular}


represent a valuable cultural asset in terms of promoting social harmony and cross-ethnic communication in Java's potentially volatile urban populations. This suggests that stronger regulation could negatively affect broader social policy goals.

Our finding that the pattern of bird-keeping (incidence and species) differs between cities illustrates the potential value of this cultural asset in terms of creating city identities. The degree to which these patterns are determined by ethnicity (culture), traditions in the city and/or the biogeographical location of a city is difficult to tease out from the data presented. Of the six cities surveyed the birdkeeping profile of Denpasar may be that most obviously influenced by cultural heritage; the popularity of chickenkeeping in Denpasar could be attributed to the important role that the cock-fights once played in Balinese village life. A second distinctive city is Bandung, on account of the popularity of canary ownership. Canaries are also popular in the city of Malang in East Java (not surveyed; Forum Kenari Mania, pers. comm.), probably because being at higher altitudes (768 and c. $600 \mathrm{~m}$ respectively) the cooler climate of these cities is more suited to the canary. This native of a temperate Atlantic island does not breed easily in lowland Jakarta, and Indonesia's first canary breeding (c. 30 years ago) is believed to have been in Bandung (Forum Kenari Mania, pers. comm.). More generally, the pattern of species kept appears to have some relationship to the ecological context of the city. For example, long-tailed shrike is more popular in the cities of East Java. This opencountry predatory species is more abundant in the dryer landscapes of East Java compared to the wetter, lusher landscapes of the west of Java (S. van Balen, pers. comm.).

Bird-keeping therefore appears to reflect and be part of the cultural, technological, and ecological heritage of a city, something that policy makers may want to promote rather than legislate against. This line of argument could be extended to include bird conservation NGOs. Organizations such as Burung (BirdLife) Indonesia are actively seeking to build local membership to maintain the legitimacy of their policy voice and generate sustainable funding streams. This membership is likely to come from the urban middle class and from individuals who appreciate birds. As we have shown, an enjoyment of birds in Java and Bali translates into keeping cage-birds; antagonizing this potential constituency by campaigning for stricter legislation could be counter-productive.

All considered, we favour the development of so-called softer policy instruments that may include market-based and voluntary mechanisms to engage a wider range of people and organizations in the governance of bird-keeping in Java and Bali. A policy approach has been developed in conjunction with bird-keeper networks, with five interlinking components: (1) market captive-bred birds as more desirable on ethical and quality grounds; (2) increase the supply of captive-bred birds; (3) set up a social marketing campaign to encourage ethical and sustainable purchasing of birds and dissuade casual purchase of birds; (4) establish a bird certification scheme to enable such choice; (5) promote the prestige of captive-bred 'ring class' birds at songbird contests (Jepson et al., 2008). This does not exclude a role for law and enforcement. A high proportion of households in our survey tried bird-keeping only for a short time. The threat of sanction coupled with a social marketing campaign could persuade such people to either avoid starting or to give up bird-keeping as a hobby. What is needed is a blend of old and new policy instruments.

\section{Acknowledgements}

We are indebted to the many people who helped with this research. The advice and assistance of Farquhar Stirling and Dindin Kusdinar at Nielsen Indonesia was invaluable for the design of our sampling frame and training of enumerators. Peter Wood, formerly of Burung Indonesia, organized and assured the quality of the survey. Made Prana, Endang Budi Utama and the committee of Pelestari Burung Indonesia contributed invaluable suggestions to the questionnaire content, and Willy Rombang, Fahrul Amama Edho and others at Burung Indonesia helped with the data compilation and assessment of the findings. Joanna Burger and Sophie Adwick helped with the preparation of the manuscript. Finally we would like to thank the teams of enumerators in the six cites for their enthusiasm and dedication in conducting the survey. This research was funded by Defra's Darwin Initiative, which draws on the wealth of biodiversity expertise within the UK to help protect and enhance biodiversity around the world.

\section{References}

Beckerman, A.P., Boots, M. \& Gaston, K.J. (2007) Urban bird declines and the fear of cats. Animal Conservation, 10, 320-325.

BirdLife International (2001) Threatened Birds of Asia: The BirdLife International Red Data Book. BirdLife International, Cambridge, UK.

CAshore, B. (2002) Legitimacy and the privatization of environmental governance: how non-state market-driven (NSMD) governance systems gain rule-making authority. Governance: An Environmental Journal of Policy, Administration and Institutions, 15, 503-529.

CITES (2009) The CITES Appendices. Http://www.cites.org/eng/app/ index.shtml [accessed 30 March 2009].

Drews, C. (2001) Wild animals and other pets kept in Costa Rican households: incidence, species and numbers. Society and Animals, 9, 107-126.

Durant, R.F., Fiorino, D.J. \& O'Leary, R. (2004) Introduction. In Environmental Governance Reconsidered, Challenges, Choices, and Opportunities (eds R.F. Durant, D.J. Fiorino \& R. O'Leary), pp. 1-27. The MIT Press, Cambridge, USA.

Erikson, P. (1997) On Native American conservation and the status of Amazonian pets. Current Anthropology, 38, 445-446. 
Holmes, D. (1995) Editorial. Kukila, 7, 85-90.

Hoyo, J.D., Elliot, A. \& Christie, D.A. (eds) (2005) Handbook of the Birds of the World (Volume 10): Cuckoo-shrikes to Thrushes. Lynx Editions, Barcelona, Spain.

IUCN (2008) 2008 IUCN Red List of Threatened Species. IUCN, Gland, Switzerland. Http://www.redlist.org [accessed 30 March 2009].

JePson, P. \& LAdLe, R.J. (2005) Bird-keeping in Indonesia: conservation impacts and the potential for substitution-based conservation responses. Oryx, 39, 442-448.

Jepson, P., Prana, M., Sujatnika \& Amana, F. (2008) Developing a certification system for captive-bred birds in Indonesia. TRAFFIC Bulletin, 22, 9-11.

Juniper, T. (2002) Spix's Macaw: The Race to Save the World's Rarest Bird. Fourth Estate, London, UK.

Kotler, P. \& Roberto, E.L. (1989) Social Marketing. Strategies for Changing Public Behaviour. The Free Press, New York, USA.

Oldfield, S. (ed.) (2003) The Trade in Wildife. Regulation for Conservation. Earthscan, London, UK.

Republic of Indonesia (1999) Government Decree No. 7 Concerning the Conservation of Plants and Wildlife. Ministry of Forestry, Jakarta, Indonesia.
Sodhi, N.S., Koh, L.P., Brook, B.W. \& N G, P.K.L. (2004) Southeast Asian biodiversity: an impending disaster. Trends in Ecology and Evolution, 19, 654-660.

Tissot, B.N. \& Hallacher, L.E. (2003) Effects of aquarium collectors on coral reef fishes in Kona, Hawaii. Conservation Biology, 17, 1759-1768.

Wilson, E.O. (2004) Biophilia. Harvard University Press, Cambridge, USA.

\section{Biographical sketches}

Paul Jepson is Course Director of Oxford University's MSc in Nature, Society and Environmental Policy. He was formerly based in Indonesia as head of the BirdLife International-Indonesia Programme (1991-1997) and as a consultant, and he conducted research on Indonesian protected area policy (1997-2001). His interest in birdkeeping and trade is located within broader research interests relating to conservation governance and bio-cultural approaches to conservation theory and practice. RICH A RD LADLE has diverse and interdisciplinary research interests that span conservation communication and public representation, extinction theory, conservation biogeography and theoretical ecology. 